\title{
The Perspectives of Primary Mathematics Teacher Candidates about Equal Sign: The EEG Case
}

\author{
Ülkü Ayvaz , Hakan Yaman, Nazan Mersin, Yasemin Yilmaz, Soner Durmuş \\ Department of Mathematics and Science Education, Faculty of Education, Abant Izzet Baysal University, Turkey
}

Copyright $\bigcirc 2017$ by authors, all rights reserved. Authors agree that this article remains permanently open access under the terms of the Creative Commons Attribution License 4.0 International License

\begin{abstract}
In this study, it was aimed to investigate the primary mathematics teacher candidates' perceptions about the equal sign within the scope of neuroscience studies. To reveal their perceptions about the equal sign, three types of addition operations were asked to the participants: $\mathrm{a}+\mathrm{b}=\square, \square=\mathrm{a}+\mathrm{b}, \mathrm{a}+\mathrm{b}=\square+\mathrm{c}$. Their brain waves were recorded by EEG device named as Neuron-Spectrum 4. Moreover, their ideas about the types of the questions were asked to support EEG data. As a result, it was found that the teacher candidates had more cognitive activity in parietal lobe while solving the questions of type two and three. In addition to this, they also showed more cognitive activity in frontal lobe for the type three questions. EEG results reveal that they had difficulty to answer these questions than the questions of type one as they also wrote on the interview form.
\end{abstract}

Keywords Brain, EEG, Equal Sign, Arithmetic Operations, Teacher Candidates

\section{Introduction}

The most complex organ of a living organism, the brain, has remained as a fascinating puzzle since the existence (Morishima, Schunk, Bruhin, Ruff, \& Fehr). The brain had failed to attract attention of people until the designation of the 1990s as the "decade of the brain" in the United States, which increased the importance placed on the brain across the world. It is remarkable that, various countries such as Denmark and Sweden, following the United States, designated different years as the year of the brain, and, today, about 70 countries celebrate a certain period in a year as "the Brain Week" (Sekman, 2016). The growing interest and awareness towards the brain seem to contribute to inter-disciplinary studies in various fields. Indeed, the joint declaration agreed by many countries stipulates that much more emphasis should be placed on the brain and the studies on the brain (Turkish Academy of Sciences, 2016).

\subsection{Education and Neuroscience}

The main objective of education is the achievement of learning by enabling students to acquire the outcomes in the curricula. In order to reach the highest level of learning possible, it is important to understand the functions of the brain and the way it operates. Yet, the brain, unlike other organs, is too complex, and its functions have not yet to be comprehended. Despite the complexity of the structure and functions of the brain, the discipline of neuroscience, which brings the fields of neurology, psychology and biology together (Goswami, 2004), provides some significant data essential for a better understanding of the brain. For that reason, the studies of neuroscience have been incorporated into different disciplines. It has been revealed that one of these disciplines is education.

It may be further argued that the fundamental motivation behind the studies on the integration of neuroscience with education is to seek an answer for the question of how learning takes places in the human brain and thus to find out the nature of learning. In this regard, the detailed information provided by these inter-disciplinary studies on the functions of the brain during learning will potentially contribute to the re-evaluation of the learning process. The data obtained by neuroscience studies may lead to new trends in education. Since the integration of neuroscience with the studies on education allows for the comprehension of the complex cognitive basis underlying many phenomena as numerical cognition (Durmuş, Yaman, Ayvaz \& Mersin, 2017).

An example may be the results of the studies seeking to reveal the individual differences. Most of the studies, which compared the brain activation patterns of gifted and non-gifted subjects through various imaging techniques, found out that these two groups of subjects significantly differed from each other based on various aspects (Alexander,O'Boyle, \& Benbow, 1996; Jausovec 1996, 1997, 1998; Jaušovec \& Jaušovec, 2004; O’Boyle, Alexander, \& Benbow, 1991). These studies demonstrated that the gifted subjects were performing the assigned tasks 
with less mental effort, regardless of the nature of the given task. The underlying reason is the more effective use of the brain areas, which is another major difference between these two groups. Since the studies observed that the brain areas related to the given task in the gifted were active in the process of completing the task whereas the active areas in the non-gifted subjects were other brain areas, besides these, which causes them to exert more mental effort. A further important finding is the presence of a connection between the right and left hemispheres among the gifted subjects. This follows that the corpus callosum, which allows communication between the hemispheres in the brain (Sousa, 2016), is more advanced in the gifted subjects (Singh \& O'Boyle, 2004). The last difference between the brain activation patterns in these two groups is the right hemisphere of the gifted subjects, which is more active. Given that creativity is one of the components of giftedness in the theories such as The Triple Ring Theory (Renzulli, 1978) and Successful Intelligence Theory (Stenberg, 1997), which are among the theories of intelligence, it may be argued that these findings revealed by the neuroscience studies provide a cognitive evidence for the claims of these theories. Since, the right hemisphere is known to be associated with creativity (Howard-Jones, Blakemore, Samuel, Summers \& Claxton, 2005; Martindale, Hines, Mitchell \& Covello, 1984). Thus, all these differences offer an insight into the reason why the gifted students differ from their non-gifted peers based on various aspects. Moreover, a further integration of neuroscience studies with the education might evolve the identification of the gifted children, which is now performed through intelligence tests.

In addition to the studies on individual differences, the integration studies on various learning difficulties may help to determine the cognitive characteristics of the individuals with such difficulties and to organize their education environments based on these characteristics. For example, the studies on dyslexia and dyscalculia (Kucian \& Rotzer, 2009; Landerl, Kadja \& Kölle, 2009; Ram-Tsur, Mevarech, Sela \& Breznitz, 2009) reported that dyscalculia results from structural and functional abnormalities in the certain areas of the brain. Hence, the education and training provided for these individuals may be revised by taking into consideration these differences (Keleş \& Kol, 2015).

\subsection{Mathematics Education and Neuroscience}

Arithmetic is one of the major subjects in the field of mathematics. Arithmetic is defined as a field involving numbers, relations between numbers, four operations with numbers and four operation-based calculations (NCTM, 1991). Mathematical concepts are linked together like the rings of a chain. Indeed, an example of such chain is that the concept of number underlies arithmetic, which also underlies algebra. An interruption in the chain may result in various difficulties in learning of more advanced subjects (Swadener and Soedjadi, 1998).

An example of such difficulties may be explained through the argument put forward by Cooper, BoultonLewis, Athew, Willss and Mutch (1997) that the lack of understanding in various structural and relational representations in arithmetic leads them to shift away from the contexts supporting algebraic thinking and thus to have difficulties in algebra. Moreover, the equal sign, a mathematical symbol representing the relationship between two expressions, has an importance place in the transition from arithmetic to algebra. For that reason, the understanding of the concept of the equal sign as a symbol indicating an outcome or action, rather than a relational symbol, (Behr, Erlwanger and Nichols, 1980, Yaman and Toluk, 2002; Yaman, Toluk and Olkun, 2003; Yaman, Ayvaz, Yılmaz, Gündüz and Durmuş, 2017) may be considered as a major reason for potential difficulties in the future.

In the field of education, besides the studies on arithmetic operations, various imaging studies have been performed on the brain activation patterns of individuals in arithmetic operations. These studies are of importance since they are useful in understanding the activities that take place in the brain while performing arithmetic operations such as addition, subtraction, multiplication, division. These studies on arithmetic operations performed by EEG and fMRI devices (Arsalidou and Taylor, 2011; Domahs and Delazer, 2005; Gullick, Wolford and Temple, 2012; Gullick and Wolford, 2014; Prabhakaran, Rypma and Gabrieli, 2001; Rosenberg-Lee et al., 2011), reported that the frontal lobe of the brain is active during arithmetic tasks. Whereas a certain part of these arithmetic tasks is only memory-based, in other words, requires a recall, some of the tasks entail merely arithmetic reasoning.

Another area of study regarding arithmetic operations is the way that numbers and operations are presented or represented. There are many ways to represent the same amount and an arithmetic operation. For instance, the number of 3 can be represented with three dots, three fingers, three beats, the third step of a stairs, the third point in a number line, three in Arabic numbers, III in Roman numerals, the word three in English, the number words in other languages, such as trois in French and drei in German. Brain-based research in the recent times have concluded that different types of representations can be utilized in the different modes of different arithmetic. Dehaene (1997) argued that whole numbers and arithmetic rules and operations tend to be verbally represented and that the estimated arithmetic and approximate values of the numbers are represented more spatially as if they were on a number line. The imaging studies showed that when individuals were asked to compare two numbers, their bilateral areas in the parietal lobe were active, and that such activations were independent of the way that numbers are presented (Le Clec'H et al.,2000; Pinel, Dehaene, Riviere \& LeBihan., 2001). On the contrary, Campbell (1994) 
stated that the presentation of numbers (words, numbers and image) is key to the process of estimating the numerical size or performing an operation. The neuropsychological and neuroimaging data indicated that calculation is linked to the left inferior and parietal cortex. The conversion between the arithmetic problems particularly in a concrete, visual, verbal and numeric format, is a major challenge in the development of arithmetic operations.

\subsection{The Purpose of the Study}

Remarkably, these studies on arithmetic operations have revealed that different areas in the brain are activated in different tasks. These activations in the areas of the brain offer an insight into the cognitive difficulty experienced by the individual during the task. The operations are typically provided to the students, who start to learn arithmetic operations as of the first years in the primary school, in a certain format $(a+b=\square)$. Thus, it is interesting to study the cognitive differences that students experience when they encounter a presentation different from the typical presentation. Hence, this study aims investigate the primary mathematics teacher candidates' perceptions about the equal sign within the framework neuroscience studies by presenting the equations in the format of $\mathrm{a}+\mathrm{b}=\square$ and $\square=\mathrm{a}+\mathrm{b}$ as well as $\mathrm{a}+\mathrm{b}=\square+\mathrm{c}$.

\section{Method}

\subsection{Method of the Research}

The study consists of two steps. In the first step, quantitative data was collected by EEG device and then an interview form was given to participants to evaluate equality questions presented them in three different formats for the collection of qualitative data. Therefore, mixed method was used in the study as research design.

\subsection{Sampling}

The participants of the study consisted of 8 primary mathematics teacher candidates registered at the Department of Mathematics Education of a state university during the summer term of the academic year of 2015-2016. These participants were selected among 45 teacher candidates with the use of the Group Hidden Figures Test developed by Witkin, Oltman, Raskin and Karp (1971). In order to eliminate cognitive style differences, only teacher candidates having field-independent cognitive style were included in the study. Therefore, purposive sampling method was used for the selection of the participants. In order to determine field-independent teacher candidates, the formula developed by Alamolhodaei (1996) was applied to test scores of the participants. According to this formula, participants who scored above the point that obtained by adding one-quarter of the standard deviation to the mean were classified as "field-independent" and below the point that obtained by subtracting one-quarter of the standard deviation from the mean were classified as "field-dependent" (Figure 1). By using the formula, 8 teacher candidates were determined as field-independent and included to the study.
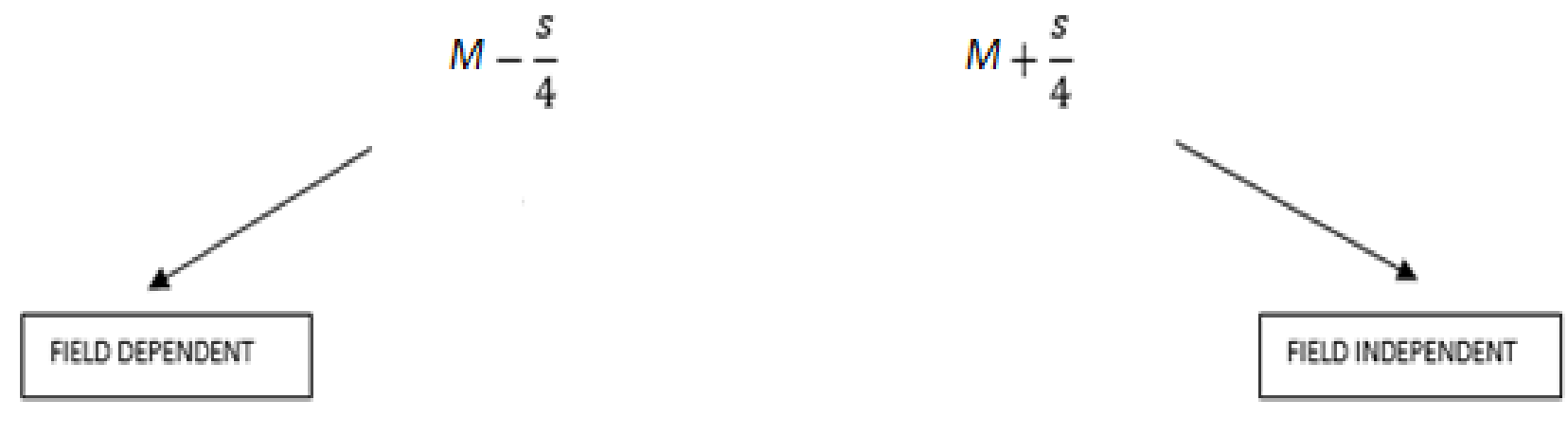

Figure 1. The selection process of the participants according to the cognitive style (M: Mean, $s$ : standard deviation) 


\subsection{Data Collection Tools}

In the study, both quantitative and qualitative data was collected. For the collection of quantitative data three different data collection tools was used: The Group Hidden Figures Test, The Addition Test, EEG device.

1) The Group Hidden Figures Test: The test was developed by Witkin, Oltman, Raskin and Karp (1971) and used in the study to determine cognitive styles of the participants of the study.

2) The Addition Test: This test consist of 45 addition questions prepared by the researchers. Three different types existed in the test: $\mathrm{a}+\mathrm{b}=\square$, $\square=\mathrm{a}+\mathrm{b}$ and $\mathrm{a}+\mathrm{b}=\square+\mathrm{c}$. As it is seen, the direction of equal is given inverse in the type two: the numbers which is summed are at the right side and the result (box) is on the left side. With this, it is aimed to present questions that teacher candidates are not used to see to put forward their perceptions about the sign of equal.

For each category, 15 addition questions weredeveloped by the researchers. The teacher candidates were asked only addition problems, since it was aimed to investigate the effect of the equal sign. So only the operation of addition was selected since addition was the one taught at first. While developing questions, the numbers of the addition questions were determined randomly. With the same reason, small numbers were preferred while writing the questions. The addition questions were presented to the participants on a computer screen and asked them to click the correct choice for the box (Figure 2).

$$
5+2=\square
$$

\section{3}

\section{7}

10

Figure 2. An example of the question of the type one

EEG Device: Oscillations in electrical potential of brain are called as "brain waves" and EEG is a neuropsychological diagnostic method for the detection of these electrical waves (Şen, 2014). The electrodes of EEG are placed according to a certain plan on four lobes of brain: frontal, parietal, occipital and central. In this study, EEG device named as Neuron-Spectrum 4 will be used to record and analyze brain waves of the participants. 16 electrodes were placed on the scalps of the participants and the places of the electrodes are determined according to 10-20 system.
After recording process of brain waves, an interview form developed by the researchers was used to collect qualitative data. In order to support quantitative data, four questions were asked to the participants to evaluate addition questions in terms of the type of questions. The questions on the interview form was given in Table 1.

Table 1. Interview Form

1. Which type of addition questions is the easiest one? Why?

2. Which type of addition questions is the hardest one? Why?

3. Does the place of the box (being on the right or left side) have any effect?

4. When primary school children are taken into consideration, which type of the addition questions they have difficult at most in your opinion? What do you suggest to overcome this difficulty?

\subsection{Data Collection Process}

First of all, for the determination of the participants, The Group Hidden Figures Test was applied to 45 primary mathematics teacher candidates and 8 of them having field-independent cognitive style were determined as the participants of the study according to the formula of Alamolhodaei (1996). Then The Addition Test was developed by the researchers and this test was presented to the participants on a computer screen. While the participants were answering addition questions, their brain waves were recorded by EEG. The EEG signals of the participants were recorded in a sound-proof room to minimize artefacts. After recording process, the interview form was given to the participants and asked them to answer the questions on the interview form.

\subsection{Analysis Techniques}

Collected data was analyzed in two steps as quantitative and qualitative. At the first step of quantitative analysis, EEG signals of the participants was analyzed. In order to analyze these signals, obtained brain waves was filtered (Band-pass filter) between $0,5-40 \mathrm{~Hz}$. Then, automatic artefact detection was used to obtain the artefacts stemming from muscle movements as eye, hand etc or other factors and these data was omitted from data set. Lastly, these digitized EEG signals were analyzed with Fast Fourier transform. Then obtained data was transferred to SPSS and Kruskal-Wallis test was carried because of the number of participants.

At the second step, data obtained from interview form was analyzed. Descriptive analysis, one of qualitative analysis methods, was used for the answers of the participants to the questions in the interview form. In the analysis, certain categories were formed based on the answers of the participants for each question. The data analysis was conducted simultaneously by the two researchers. Following the determination of the categories, the researchers encoded data in order to test the inter-encoder reliability. The percentage of agreement 
between the researchers was calculated to be $93 \%$. Following that, the differences between the researchers were eliminated and the analyses were performed based on the specified categories.

\section{Findings}

In the study, brain waves of the participants were recorded by EEG and then the interview form was given to participants to evaluate the questions presented to them in three different categories. Therefore, findings were presented under two categories: EEG recording and interview form.

\subsection{EEG Recording}

When research on arithmetic operations are investigated, it is seen that frontal and parietal lobes are active while solving arithmetic operations (Arsalidou and Taylor, 2011; Domahs and Delazer, 2005; Gullick, Wolford and Temple, 2012; Gullick and Wolford, 2014; Le Clec'H et al., 2000Pinel, Dehaene, Riviere and LeBihan., 200; Prabhakaran, Rypma and Gabrieli, 2001; Rosenberg-Lee et al., 2011; Sousa, 2016). If operation is simple and brain can handle it automatically, then frontal lobe is more active. When harder operations requiring some strategies are presented, on the other hand, it is seen that parietal lobe's activity is higher. Therefore, it can be said that frontal lobe is active for the solution of basic arithmetic operations while difficulty of operations is increased, parietal lobe is more active. In the study, participants were presented addition operations and so findings related to frontal and parietal lobes were investigated.

Neural activity changes in alfa waves $(8-12 \mathrm{~Hz})$ are related to individual cognitive and memory performances in general (Klimesch, 1999). Beta waves, on the other hand, are basically recorded from parietal and frontal lobes during typical activation of these lobes and when an individual direct his/her attention to a certain activity, alfa waves give place to high-frequency beta waves with low amplitudes (Guyton \& Hall, 2011). Moreover, it is stated that beta waves are recorded as a result of extreme mental activity (Canan, 2013). Since cognitive activity are related with alfa and beta waves, results in frontal and parietal lobes related to these waves were given.

\section{Alfa waves}

In order to investigate differences in alfa waves according to type of questions presented to the participants, Kruskal Wallis test was performed. Test results for frontal and parietal lobes are seen in Table 2 and 3, respectively.

According to the results, significance difference was not found in any of the electrodes of frontal lobe in terms of the type of question. When the microvolt values seen in Table 2 are examined, on the other hand, it is seen that the questions in the type three have the least values when it is compared to two other types for all of the electrodes in frontal lobe. Decrease of alfa in spectral power is considered generally as the indicator of brain activation (Alexander, O’Boyle, \& Benbow, 1996). This means that an inverse relationship exist between alfa waves and cognitive activity. Therefore, it is understood that the participants exhibited more cognitive activity for the type three. Based on this conclusion, it can be claimed that the questions of the type three are harder than those of others because of requiring more mental activity.

Table 2. Kruskal Wallis Test Results for Alfa Waves in Frontal Lobe

\begin{tabular}{|c|c|c|c|c|c|c|}
\hline Electrode & $\begin{array}{c}\text { Type of } \\
\text { Question }\end{array}$ & $\mathrm{n}$ & $\begin{array}{l}\text { Mean } \\
\text { Rank }\end{array}$ & df & Chi-square & $\mathrm{p}$ \\
\hline \multirow{3}{*}{$\mathrm{F} 3$} & $\mathrm{a}+\mathrm{b}=\square$ & 8 & 13,25 & \multirow{3}{*}{2} & \multirow{3}{*}{, 347} & \multirow{3}{*}{, 841} \\
\hline & $\square=\mathrm{a}+\mathrm{b}$ & 8 & 12,94 & & & \\
\hline & $\mathrm{a}+\mathrm{b}=\square+\mathrm{c}$ & 8 & 11,31 & & & \\
\hline \multirow{3}{*}{$\mathrm{F} 4$} & $\mathrm{a}+\mathrm{b}=\square$ & 8 & 12,56 & \multirow{3}{*}{2} & \multirow{3}{*}{1,165} & \multirow{3}{*}{, 558} \\
\hline & $\square=\mathrm{a}+\mathrm{b}$ & 8 & 14,38 & & & \\
\hline & $\mathrm{a}+\mathrm{b}=\square+\mathrm{c}$ & 8 & 10,56 & & & \\
\hline \multirow{3}{*}{ F7 } & $\mathrm{a}+\mathrm{b}=\square$ & 8 & 13,00 & \multirow{3}{*}{2} & \multirow{3}{*}{1,186} & \multirow{3}{*}{, 553} \\
\hline & $\square=\mathrm{a}+\mathrm{b}$ & 8 & 14,13 & & & \\
\hline & $\mathrm{a}+\mathrm{b}=\square+\mathrm{c}$ & 8 & 10,38 & & & \\
\hline \multirow{3}{*}{ F8 } & $\mathrm{a}+\mathrm{b}=\square$ & 8 & 12,75 & \multirow{3}{*}{2} & \multirow{3}{*}{, 260} & \multirow{3}{*}{, 878} \\
\hline & $\square=a+b$ & 8 & 13,25 & & & \\
\hline & $\mathrm{a}+\mathrm{b}=\square+\mathrm{c}$ & 8 & 11,50 & & & \\
\hline
\end{tabular}

It is expected that the questions of type two are harder than those of the type one, yet the microvolt values put forward an inverse result. That is, the participants' microvolt values related to the type two are higher than those of the type one. Therefore, it is understood that the participants answered the questions of the type two with less cognitive activity when it is compared to the type one. More activation for the type two was obtained only in F3 as seen in the table.

Table 3. Kruskal Wallis Test Results for Alfa Waves in Parietal Lobe

\begin{tabular}{|c|c|c|c|c|c|c|}
\hline Electrode & $\begin{array}{c}\text { Type of } \\
\text { Question }\end{array}$ & & $\begin{array}{l}\text { Mean } \\
\text { Rank }\end{array}$ & $\mathrm{df}$ & Chi-square & $\mathrm{p}$ \\
\hline \multirow{3}{*}{ P3 } & $\mathrm{a}+\mathrm{b}=\square$ & 8 & 12,94 & \multirow{3}{*}{2} & \multirow{3}{*}{ 159, } & \multirow{3}{*}{,923 } \\
\hline & $\square=\mathrm{a}+\mathrm{b}$ & 8 & 11,69 & & & \\
\hline & $\mathrm{a}+\mathrm{b}=\square+\mathrm{c}$ & 8 & 12,88 & & & \\
\hline \multirow{3}{*}{ P4 } & $\mathrm{a}+\mathrm{b}=\square$ & 8 & 13,38 & \multirow{3}{*}{2} & \multirow{3}{*}{,637 } & \multirow{3}{*}{, 970} \\
\hline & $\square=\mathrm{a}+\mathrm{b}$ & 8 & 13,25 & & & \\
\hline & $\mathrm{a}+\mathrm{b}=\square+\mathrm{c}$ & 8 & 10,88 & & & \\
\hline
\end{tabular}

Test results for alfa waves in parietal lobe are seen in Table 3. Any significance differences were obtained in parietal lobe in terms of the type of question. According to microvolt values of the electrodes $\mathrm{P} 3$ and $\mathrm{P} 4$, however, it can be said that the participants showed less activation for the questions in type one. For the questions of the type two and three, on the other hand, such a pattern does not exist. 
Since the participants showed more activation in $\mathrm{P} 3$ for the type two whereas more activation was found in $\mathrm{P} 4$ for the type three.

\section{Beta waves}

In order to investigate differences in beta waves according to type of questions presented to the participants, Kruskal Wallis test was performed. Test results for frontal and parietal lobes are seen in Table 4 and 5, respectively.

Table 4. Kruskal Wallis Test Results for Beta Waves in Frontal Lobe

\begin{tabular}{|c|c|c|c|c|c|c|}
\hline Electrode & $\begin{array}{c}\text { Type of } \\
\text { Question }\end{array}$ & $\mathrm{n}$ & $\begin{array}{l}\text { Mean } \\
\text { Rank }\end{array}$ & $\mathrm{df}$ & Chi-square & $\mathrm{p}$ \\
\hline \multirow{3}{*}{ F3 } & $\mathrm{a}+\mathrm{b}=\square$ & 8 & 14,13 & \multirow{3}{*}{2} & \multirow{3}{*}{1,242} & \multirow{3}{*}{, 537} \\
\hline & $\square=\mathrm{a}+\mathrm{b}$ & 8 & 13,06 & & & \\
\hline & $\mathrm{a}+\mathrm{b}=\square+\mathrm{c}$ & 8 & 10,31 & & & \\
\hline \multirow{3}{*}{$\mathrm{F} 4$} & $\mathrm{a}+\mathrm{b}=\square$ & 8 & 12,06 & \multirow{3}{*}{2} & \multirow{3}{*}{,185 } & \multirow{3}{*}{,912 } \\
\hline & $\square=\mathrm{a}+\mathrm{b}$ & 8 & 13,38 & & & \\
\hline & $\mathrm{a}+\mathrm{b}=\square+\mathrm{c}$ & 8 & 12,08 & & & \\
\hline \multirow{3}{*}{ F7 } & $\mathrm{a}+\mathrm{b}=\square$ & 8 & 14,38 & \multirow{3}{*}{2} & \multirow{3}{*}{,849 } & \multirow{3}{*}{,654 } \\
\hline & $\square=\mathrm{a}+\mathrm{b}$ & 8 & 11,50 & & & \\
\hline & $\mathrm{a}+\mathrm{b}=\square+\mathrm{c}$ & 8 & 11,63 & & & \\
\hline \multirow{3}{*}{ F8 } & $\mathrm{a}+\mathrm{b}=\square$ & 8 & 12,25 & \multirow{3}{*}{2} & \multirow{3}{*}{,020 } & \multirow{3}{*}{,990 } \\
\hline & $\square=\mathrm{a}+\mathrm{b}$ & 8 & 12,50 & & & \\
\hline & $\mathrm{a}+\mathrm{b}=\square+\mathrm{c}$ & 8 & 12,75 & & & \\
\hline
\end{tabular}

Obtained results shows that any significance difference existed for beta wave in any electrodes of the frontal lobe in terms of the type of question. For the electrodes in right hemisphere (F4 and F8), the questions in type two and three had higher microvolt values whereas an inverse result existed for the left hemisphere. That is, in F3 and F7 which were located on the left part of the scalp, higher microvolt values were obtained for the questions of the type one.

Table 5. Kruskal Wallis Test Results for Beta Waves in Parietal Lobe

\begin{tabular}{|c|c|c|c|c|c|c|}
\hline Electrode & $\begin{array}{c}\text { Type of } \\
\text { Question }\end{array}$ & & $\begin{array}{l}\text { Mean } \\
\text { Rank }\end{array}$ & df & Chi-square & $\mathrm{p}$ \\
\hline \multirow{3}{*}{ P3 } & $\mathrm{a}+\mathrm{b}=\square$ & 8 & 14,38 & \multirow{3}{*}{2} & \multirow{3}{*}{1,631} & \multirow{3}{*}{,442 } \\
\hline & $\square=\mathrm{a}+\mathrm{b}$ & 8 & 13,13 & & & \\
\hline & $\mathrm{a}+\mathrm{b}=\square+\mathrm{c}$ & 8 & 10,00 & & & \\
\hline \multirow{3}{*}{ P4 } & $\mathrm{a}+\mathrm{b}=\square$ & 8 & 11,31 & \multirow{3}{*}{2} & \multirow{3}{*}{,640 } & \multirow{3}{*}{, 726} \\
\hline & $\square=\mathrm{a}+\mathrm{b}$ & 8 & 14,06 & & & \\
\hline & $\mathrm{a}+\mathrm{b}=\square+\mathrm{c}$ & 8 & 12,13 & & & \\
\hline
\end{tabular}

Kruskal Wallis test results reveals that the participants had similar microvolt values in parietal lobe in terms of beta waves. Therefore, significant difference was not found both in P3 and P4 in terms of the type of question. Although some pattern were obtained in other analysis results above, any pattern was not found related to the microvolt values in parietal lobe for beta waves. The questions of type one had the highest microvolt values in P3 whereas the least microvolt values in P4. The highest microvolt values are obtained for the type two in P4 while it had lower value than type one and higher value than type three in P3.

\subsection{Interview form}

The interview form includes four questions. These questions were analyzed with descriptive analysis and the results are seen in tables below.

Table 6. Categories related to First Question

\begin{tabular}{ccc}
\hline $\begin{array}{c}\text { Part of the } \\
\text { Question }\end{array}$ & Category & $\begin{array}{c}\text { Prospective } \\
\text { teacher }\end{array}$ \\
\hline $\begin{array}{c}\text { The Easiest } \\
\text { Question }\end{array}$ & Type one & $\begin{array}{c}\text { P2, P3, P4, P5, P6, } \\
\text { P8 }\end{array}$ \\
\cline { 2 - 3 } & Type one and two & P1, P7 \\
\cline { 2 - 3 } Reason & $\begin{array}{c}\text { No answer } \\
\text { Being accustomed to the } \\
\text { type of the question } \\
\text { (answer of the operation is } \\
\text { on the right) }\end{array}$ & P3, P4, P5, P6, P8 \\
\cline { 2 - 3 } & $\begin{array}{c}\text { One-step operation (only } \\
\text { addition) }\end{array}$ & P2, P7 \\
\hline
\end{tabular}

The first question is "Which type of addition questions is the easiest one? Why?" The answers of the participants are seen in Table 6. It is found that 6 teacher candidates thought that the questions of the type one were the easiest while two of them also answer the questions of type two easily. According to 2 teacher candidates, since the questions required one-step operation, they were the easiest. Most of the teacher candidates, on the other hand, explained their reasons as being accustomed to the type of the question. Some examples of the reasons of the participants are as follows:

- $\quad a+b=\square$ was the easiest. From the beginning of first grade while we were making addition operation, the presentation format of operation was like this. I do not remember that our teachers ask an operation like $\square=a+b$. I remembered that our teachers asked operations like $a+b=\square+c$, yet their frequency was quite less. These type of questions were asked in exams generally." (P3)

- $\quad$ " $a+b=\square$ was the easiest. Because we were used to see this format from the beginning of our mathematics education" (P5)

- $\quad " a+b=\square$ was the easiest. Because this is ordinary format of presenting operations" (P8)

- The type one and two were easier. Because the last one requires two operations." (P7)

Table 7. Categories related to Second Question

\begin{tabular}{ccc}
\hline $\begin{array}{c}\text { Part of the } \\
\text { Question }\end{array}$ & Category & $\begin{array}{c}\text { Prospective } \\
\text { teacher }\end{array}$ \\
\hline \multirow{2}{*}{$\begin{array}{c}\text { The Hardest } \\
\text { Question }\end{array}$} & Type two & P3, P4 \\
\cline { 2 - 3 } & Type three & P1, P2, P5, P6, P7, \\
\hline \multirow{2}{*}{ Reason } & $\begin{array}{c}\text { Not being accustomed to } \\
\text { the type of the question } \\
\text { (answer of the operation is } \\
\text { on the left) }\end{array}$ & P3, P4 \\
\cline { 2 - 3 } & $\begin{array}{c}\text { Two-step operation } \\
\text { (addition and subtraction) }\end{array}$ & P1, P2, P5, P6, P7, \\
\hline
\end{tabular}


"Which type of addition questions is the hardest one? Why?" is the second question and the categories created with the answers of the participants are given in Table 7 . Six teacher candidates stated that the questions of the type two are the hardest while two of them thought that it was the type two including hardest questions. When accuracy of their answers were also examined, it was found that all of the participants give wrong answer to " $7+8=\square+9$ " which is a question of the type three. In addition to this, 3 teacher candidates also answered some other questions of the type three wrongly. According to the participants, these questions were the hardest because of requiring two operations to answer. On the other hand, it was also found that there were also 4 teacher candidates could not answer some of the questions of the type two correctly. Not being accustomed to the type of the question can be the reason of being the hardest question type as two teacher candidates stated. Explanations of some of the participants are given below:

- $\quad$ The type three was the hardest. Because it requires two operations, like addition and subtraction." (P1)

- $\quad$ " $a+b=\square+c$ was the hardest. Because I had to know sum of the left side, subtract the number on the right side from this sum and write the result to the box." (P2)

- "I thought that the second type was the hardest. Because teachers always ask questions like $a+b=\square$ and therefore we are get accustomed to this type of questions. Therefore, it is thought that something wrong with the questions of type two. Moreover, we know that the numbers that we make any operations are on the right and therefore I had difficulty to focus on the right side $(\square=a+b)$ to sum the numbers." (P3)

- $\quad$ " $\square=a+b$ was the hardest because of the place of the equal sign, not the difficulty of the questions. Since the questions were presented in a different format that we are used to see" (P4)

Table 8. Categories related to Third Question

\begin{tabular}{cc}
\hline Category & Prospective teacher \\
\hline No effect & P1, P8 \\
\hline Difficulty in perceiving & P2, P3, P4, P5, P6, P7 \\
\hline Can be thought as wrong & P3 \\
\hline Increase of time in answering & P5, P7,
\end{tabular}

The direction of equal was changed in the questions of type two to investigate the perceptions of the teacher candidates about the sign of equal. Therefore, the third question (Does the place of the box (being on the right or left side) have any effect?) asked them whether this affected them or not while answering. Although the participants were primary mathematics teacher candidates, most of them stated that they had difficulty in perceiving because of the direction of the equal sign. They also said that this caused them to answer the questions in more time. When their reaction time to the questions of type two were examined, it was found that they really answered these questions in more time. Two teacher candidates, on the other hand, stated that the direction of equal did not affect them in any way. Explanations of the teacher candidates for the third question are as follow:

- “Any effects for me.” (P1)

- "I had difficulty in perceiving at first. Moreover, I think that a children who do not see this an operation like $\square=a+b$ may think that there is a problem with the presentation format of the operation.” (P3)

- "We are used to see operations like $a+b=\square$ causing us to have difficulty in perceiving the operation. Therefore, while answering, it made me feel worried and click the correct choice in more time" (P5)

- "It differs in terms of reaction time because of not being accustomed. Therefore, it may cause a primary school student to think wrongly." (P7)

Table 9. Categories related to Fourth Question

\begin{tabular}{|c|c|c|}
\hline $\begin{array}{l}\text { Part of the } \\
\text { Question }\end{array}$ & Category & $\begin{array}{c}\text { Prospective } \\
\text { teacher }\end{array}$ \\
\hline \multirow{2}{*}{$\begin{array}{l}\text { The Hardest } \\
\text { Question }\end{array}$} & Type two & P4, P8 \\
\hline & Type three & $\begin{array}{c}\text { P1, P2, P3, P5, P6, } \\
\text { P7 }\end{array}$ \\
\hline \multirow[b]{3}{*}{ Reason } & Two-step operation & P1, P3, P5, P7 \\
\hline & No answer & $\mathrm{P} 2, \mathrm{P} 6$ \\
\hline & $\begin{array}{l}\text { Not being accustomed to } \\
\text { the type of the question } \\
\text { (answer of the operation is } \\
\text { on the left) }\end{array}$ & P4, P8 \\
\hline \multirow{4}{*}{ Suggestion } & $\begin{array}{l}\text { More activities requiring } \\
\text { mental operations }\end{array}$ & P1 \\
\hline & $\begin{array}{l}\text { More experience with this } \\
\text { type of questions }\end{array}$ & $\mathrm{P} 2, \mathrm{P} 5, \mathrm{P} 6$ \\
\hline & No answer & $\mathrm{P} 3, \mathrm{P} 7, \mathrm{P} 8$ \\
\hline & $\begin{array}{l}\text { Giving examples including } \\
\text { this type of question }\end{array}$ & P4 \\
\hline
\end{tabular}

The last question of the interview form is "When primary school children are taken into consideration, which type of the addition questions they have difficult at most in your opinion? What do you suggest to overcome this difficulty?" Parallel to the answers to the second question, 6 teacher candidates stated that the type three included the hardest questions for primary school children while two of them thought that primary school children could have more difficulty in answering the questions of the type two. The former group's reason for this is that the type three included questions requiring two operations. The latter, on the other hand, stated that children could have difficulty because of not being accustomed to the type of question. The teacher candidates explained their reasons as follows: 
- $\quad$ "I think it is the type three because of requiring both addition and subtraction." (P1, P3)

- "I think primary school children have more difficult in questions like $a+b=\square+c$. Because it is more complicated and requires operations more than one." (P5)

- "They have more difficulty in the questions of type two in my opinion. Because $a+b=\square$ is a stereotype format for children. Therefore, they may not receive $\square=a+b$ as an addition operation." (P4)

As a suggestion to handle this difficulty, the teacher candidates offered to have more activities requiring mental operations $(\mathrm{n}=1)$, more experience with this type of question $(\mathrm{n}=3)$ and giving examples including this type of question $(\mathrm{n}=1)$. Three teacher candidates, however, did not offer any solutions.

\section{Results, Conclusions and Recommendations}

This study aims to investigate the primary mathematics teacher candidates' perceptions about the equal sign within the scope of neuroscience studies. To reveal their perceptions about the equal sign, there types of addition operations were asked to the participants: $\mathrm{a}+\mathrm{b}=\square, \square=\mathrm{a}+\mathrm{b}$, $\mathrm{a}+\mathrm{b}=\square+\mathrm{c}$. By recording their brain waves with EEG during answering three type of addition questions, it was aimed to obtain differences in their brain structures according to the types of questions. Moreover, their ideas about the types of the questions were asked to support EEG data.

Alfa and beta waves of the participants were examined due to the fact that changes in these waves are stated to related with cognitive activity (Canan, 2013; Guyton \& Hall, 2011; Klimesch, 1999). However any significance differences were obtained in terms of the type of the questions in both alfa and beta waves. Although these differences were not statistically significant, they have important implications about the equal sign. It was found that for the questions of the type one, the participants had higher alfa power than those of the type two in frontal lobe. That is, the participants showed more cognitive activity in frontal lobe for this type. In the frontal lobe, on the other hand, the alfa power of the participants are lower for the questions of the type two. This result reveals that the participants showed more cognitive activity for this type than the type one in the parietal lobe. Based on this result, it can be said that the participants answered the questions of the type one more easily without needing a strategy. Since it is stated that frontal lobe is active during the solution of basic arithmetic operations that can be answered automatically (Arsalidou and Taylor, 2011; Domahs and Delazer, 2005; Gullick, Wolford and Temple, 2012; Gullick and Wolford, 2014; Sousa, 2016). When the direction of equal is changed ( $\square=a+b)$, however, it is seen that cognitive activity of the participants were higher in parietal lobes. When it is taken into account that parietal lobe is more active in solving arithmetic operations that are more difficult (Le Clec'H et al., 2000; Pinel, Dehaene, Riviere \& LeBihan., 2001), it is understood that questions like $\square=\mathrm{a}+\mathrm{b}$ are harder than those presented with ordinary format $(a+b=\square)$. There exist only one difference between this two types of problems, that is, the direction of the equal sign. Therefore, it put forwards a significant finding that only change of the direction of the equal sign causes the teacher candidates have more difficulty in answering to the questions. Since the participants are prospective mathematics teachers and it is thought that these type of arithmetic operations are quite easy for them. They answered correctly all of the questions of the type one and most of the questions of the type two surely, yet the difference in their brain structures in terms of the type of questions reveals that there exist a difference probably stemming from the direction of the equal sign.

If the alfa powers of participants for the questions of the type three are examined, it is seen that they have the lowest microvolt values in the frontal lobe. In the parietal lobe, on the other hand, the microvolt value is the lowest for P4 while it was higher than that of the type two questions. According to this, it can be said that the participants had lower alfa power for the questions of the type three in frontal and parietal lobes. That is, they showed higher cognitive activity in both of the lobes. Therefore, it can be said that this type is probably the hardest one for the participants. Since they answered addition operations both automatically and with strategies because of the activation of both of the lobes. If the structure of the questions of the type three $(\mathrm{a}+\mathrm{b}=\square+\mathrm{c})$ is examined, it is seen that they are different than the questions of other two types because of requiring operations more than one. While answering one can sum $a$ and $b$ and then subtract $c$ from this sum to find the value of the box. Or s/he can develop a strategy as follow: for the operation $3+5=\square+6$, for example, s/he can think that since 6 is one more than 5 , then the value of the box has to be one less than 3 for two sides of the equal to be equal. Because of this different solution options and including two-step operations, the participants could show more activity in both frontal and parietal lobes. Moreover, in the electrodes located on right hemisphere (F4, F8, P4), it is found that microvolt values of the type three than those of the type one beta waves. Since beta waves are recorded when one direct his/her attention to a certain activity (Guyton \& Hall, 2011) and right hemisphere is known as related to creativity (Howard-Jones, Blakemore, Samuel, Summers \& Claxton, 2005; Martindale, Hines, Mitchell \& Covello, 1984), solution of type two questions could cause participants to direct their attention some cognitive activity that requires creativity.

When the qualitative data is examined, it is seen that the participants gave explanations related to the type of the questions that supported the findings of EEG recording. As obtained with the changes in alfa waves, all of them said that the questions of the type one are the easiest. Since 
these questions are one-step and they are get accustomed to the presentation format of the questions $(a+b=\square)$. In addition to this result, most of them also stated that they had difficulty in answering the questions of the type three more while the questions of the type two were harder for 2 of the teacher candidates. This result is also parallel to the results obtained in EEG recordings. As a reason, they proposed that the type three questions included two-step operations. Moreover, as expected, since direction of the equal sign collides their habits that they have obtained from the beginning of their education life, they had difficulties in perceiving. Since they could not answer automatically as they did in the type one questions, their reaction time to the questions were longer. Because of these reasons, the teacher candidates also thought that primary school children have difficulties in the questions of type two and there at most. Indeed, researches about the equal sign revealed that children had difficulties to answer and even gave wrong answers to the questions as $\square=\mathrm{a}+\mathrm{b}$ or $\mathrm{a}+\mathrm{b}=\square+\mathrm{c}$ (Behr, Erlwanger \& Nichols, 1980, Yaman ve Toluk, 2002; Yaman, Toluk \& Olkun, 2003; Yaman, Ayvaz, Y1lmaz, Gündüz \& Durmuş, 2017). When it is taken into account that the participants of the study are prospective mathematics teachers and they showed more cognitive activation to answer these type of questions, it is quite possible that primary school children have more difficulty to understand these questions.

All in all, this study is conducted to reveal perceptions of prospective mathematics teachers about the equal sign. The results put forward that even prospective mathematics teachers had difficulties when the direction of the equal sign was changed although they know equal sign represents an equal regardless of the place of the result of the operation $(a+b=\square$ or $\square=a+b)$. Therefore, as the participants of this study suggested, these type of questions should be presented to children to make them understand what really the equal sign means. Moreover, after children understand that the equal sign expresses relationship between two quantities with the help of these type of questions, further neuroscience studies can be conducted to investigate effects of understating equal as a relationship on brain structures of children.

\section{REFERENCES}

[1] Alamolhodaei, H. (1996). A study in higher education calculus and students' learning styles. (Unpublished doctoral dissertation). University of Glasgow, England.

[2] Alexander, J. E., O'Boyle, M. W., \& Benbow, C. P. (1996). Developmentally advanced EEG alpha power in gifted male and female adolescents. International Journal of Psychophysiology, 23(1), 25-31.

[3] Arsalidou, M., Taylor, M.J., (2011). Is $2+2=4$ ? Meta-analyses of brain areas needed for numbers and calculations. NeuroImage 54, 2382-2393.

[4] Behr, M. J., Erlwanger, S., \& Nichols, E. (1980). How children view the equals sign. Mathematics Teaching, 92, 13-15.

[5] Campbell, J.I., 1994. Architectures for numerical cognition. Cognition 53, 1-44.

[6] Canan, S., (2013). Merkezi Sinir Sistemi. Retrieved 01.06.2013, from http://www.sinancanan.net.tr/

[7] Cooper, T. J., Boulton-Lewis, G., Athew, B., Willss, L. ve Mutch, S. (1997). The transition arithmetic to algebra: Initial understandings of equals, operations and variable. International Group for the Psychology of Mathematics Education, 21(2), 89-96.

[8] Dehaene, S. (1997). The number sense. New York:Oxford University Press.

[9] Domahs, F., \& Delazer, M. (2005). Some assumptions and facts about arithmetic facts. Psychol Sci 47(96), 111.

[10] Goswami, U. (2004). Neuroscience and education. British Journal of Educational Psychology, 74(1), 1-14. doi: 10.1348/000709904322848798

[11] Gullick MM, Wolford G, Temple E (2012): Understanding less than nothing: Neural distance effects for negative numbers. Neuroimage 62, 542-554.

[12] Gullick, M. M., \& Wolford, G. (2014). Brain systems involved in arithmetic with positive versus negative numbers. Hum Brain Mapp, 35(2), 539-551. doi: 10.1002/hbm.22201.

[13] Guyton, A. C. \& Hall, J. E. (2011). B. Çağlayan, Z. Solakoğlu, İ. Alican (Çev. Ed.) (11. Bask1), Tıbbi Fizyoloji. İstanbul: Nobel Tip Kitabevleri; 356-412.

[14] Howard-Jones, P.A., Blakemore, S.J., Samuel, E.A., Summers, I.R., Claxton, G. (2005). Semantic divergence and creative story generation: An fMRI investigation. Cognitive Brain Research. 25, 240-250.

[15] Jaušovec, N. (1996). Differences in EEG alpha activity related to giftedness. Intelligence, 23(3), 159-173. doi: http://dx.doi.org/10.1016/S0160- 2896(96)90001-X

[16] Jausovec, N. (1997). Differences in EEG activity during the solution of closed and open problems. Creativity Research Journal, 10(4), 317-324.

[17] Jaušovec, N. (1998). Are gifted individuals less chaotic thinkers?. Personality and Individual Differences, 25(2), 253-267.

[18] Jaušovec, N., \& Jaušovec, K. (2004). Differences in induced brain activity during the performance of learning and working-memory tasks related to intelligence. Brain and Cognition, 54(1), 65-74.

[19] Keleş, E., \& Kol, E. (2015). An Overview of the brain imaging techniques from the education perspective. Elementary Education Online, 14(1), 349-363.

[20] Klimesch, W. (1999). EEG alpha and theta oscillations reflect cognitive and memory performance: A review and analysis. Brain Research Reviews, 29(2-3), 169-195.

[21] Kucian, K., \& Rotzer, S. (2009). Brain functions and training intervention in children with developmental 
dyscalculia. In Paper presented at the EARLI Advanced Study Colloquium on Cognitive Neuroscience Meets Mathematics Education Brugge, Belgium.

[22] Landerl, K., Kajda, B., \& Kölle, C. (2009). Typical and atypical development of basic numerical skills. In Paper presented at the EARLI Advanced Study Colloquium on Cognitive Neuroscience Meets Mathematics Education Brugge, Belgium.

[23] Le Clec'H. G., Dehaene, S., Cohen, L., Mehler, J., Dupoux, E., Poline, J. B., Lehericy, S., van de Moortele, P. F., \& Le Bihan, D. (2000). Distinct cortical areas for names of numbers and body parts independent of language and input modality. NeuroImage, 12, 381-391.

[24] Looi, C. Et al. (2016).S. The neuroscience of mathematical cognition and learning. Durmuş, H. Yaman, Ü. Ayvaz, N. Mersin (Çev.). Retrieved from http://ajanda.ibu.edu.tr/wp-content/uploads/2017/08/Matem atiksel-Bili\%C5\%9F in-ve-\%C3\%96\%C4\%9Frenmenin-Sin irbilimi-Final.pdf on 10 May, 2017.

[25] Martindale, C., Hines, D., Mitchell, L. and Covello, E. (1984). EEG alpha asymmetry and creativity. Personality and Individual Differences, 5, 77-86.

[26] Morishima, Y., Schunk, D., Bruhin, A., Ruff, C. C., \& Fehr, E. (2012). Linking brain structure and activation in temporoparietal junction to explain the neurobiology of human altruism. Neuron, 75(1), 73-79.

[27] O'boyle, M.W., Alexander, J.E. ve Benbow, C.P., (1991). Enhanced right hemisphere activation in the mathematically precocious: A preliminary EEG investigation. Brain and Cognition, 17(2), 138-153.

[28] Pinel, P., Dehaene, S., Riviere, D., \& LeBihan, D. (2001). Modulation of parietal activation by semantic distance in a number comparison task. NeuroImage, 14, 1013-1026.

[29] Prabhakaran, V., Rypma, B., Gabrieli, J.D., 2001. Neural substrates of mathematical reasoning: a functional magnetic resonance imaging study of neocortical activation during performance of the necessary arithmetic operations test. Neuropsychology 15, 115-127.

[30] Ram-Tsur, R., Mevarech, Z., Sela, I., \& Breznitz, Z. (2009). Neuro-mechanism of the mathematical skills: Application of cross-modalities hypothesis. In Paper presented at the EARLI Advanced Study Colloquium on Cognitive Neuroscience Meets Mathematics Education Brugge, Belgium.
[31] Renzulli, J. S. (1978). What makes giftedness? Reexamining a definition. Phi Delta Kappan, 60(3), 180.

[32] Rosenberg-Lee M, Chang TT, Young CB, Wu S, Menon V (2011): Functional dissociations between four basic arithmetic operations in the human posterior parietal cortex: A cytoarchitectonic mapping study. Neuropsychologia 49, 2592-2608.

[33] Sekman, M. (2016). Her şey beyinde başlar. İstanbul: Alfa Yayıncilık.

[34] Singh, H. ve O'Boyle, M.W., (2004). Interhemispheric interaction during globallocal processing in mathematically gifted adolescents, average-ability youth, and college students. Neuropsychology, 18(2), 371-377

[35] Sousa, D. A. (2016). How the brain learns. Corwin Press.

[36] Stenberg, R. J. (1997). A triarchic view of giftedness: Theory and practice. In N. Colangelo \& G. Davis (Eds.), Handbook on gifted education (2nd ed.). Needham Heights, MA: Allyn and Bacon

[37] Swadener, M., \& Soedjadi, R. (1988). Values, mathematics education, and the task of developing pupils' personalities: An Indonesian perspective. In A. J. Bishop (Ed.), Mathematics education and culture (pp. 193-208). Dordrecht, The Netherlands: Kluwer Academic Publishers.

[38] Şen, T. (2014). Nöbet tutan hemşireler ile tutmayan hemşirelerin EEG'lerinin karşılaştırılması. (Yayımlanmamış doktora tezi). Van Yüzüncü Y1l Üniversitesi, Türkiye.

[39] Turkish Academy of Sciences (2016). G-Bilim Akademileri 2016 Ortak Bildirileri. Retrirved from http://www.tuba.gov.tr/news/g-bilim-akademileri-2016-orta k-bildirileri-aciklandi/id/1504 on 5 May, 2016.

[40] Witkin, H. A., Oltman, P. K., Raskin, E., \& Karp, S. A. (1971).The group embedded figures test. Palo Alto, CA: Consulting Psychological Press.

[41] Yaman, H, Toluk, Z, Oklun, S. (2003). İlköğretim öğrencileri eșit işaretini nasıl algılamaktadırlar? Hacettepe Üniversitesi Eğitim Fakültesi Dergisi, 24,142-151.

[42] Yaman, H. \& Toluk, Z. (2002). İlköğretim öğrencilerinin eşitlik kavramını algılayışları üzerine bir çalışma. XI. Ulusal Eğitim Bilimleri Kongresi, Kıbrıs.

[43] Yaman, H., Ayvaz, Ü., Y1lmaz, Y., Gündüz N., and Durmuş, S. (2017). İlkokul ve ortaokul ögrencilerinin eşit işaretini algılamaları üzerine bir araştırma. Türk Bilgisayar ve Matematik Sempozyumu 3, Turkey. 